\title{
Effects of Antioxidant, Anti-Collagenase, Anti- Elastase, Anti-Tyrosinase of The Extract and Fraction From Turbinaria decurrens Bory.
}

\author{
Arief Nurrochmad ${ }^{1} *$, Wirasti ${ }^{2,6}$, Arifin Dirman ${ }^{3,6}$, Endang Lukitaningsih4, Adillah \\ Rahmawati6, and Nanang Fakhrudin 5
}

1Dept of Pharmacology and Clinical Pharmacy, Faculty of Pharmacy, Universitas Gadjah Mada, Sekip Utara Yogyakarta 55281, Indonesia 2.STIKES Muhammadiyah Pekajangan, Pekalongan 55172, Indonesia 32Dinas Kesehatan Daerah Kota a Palu, Provinsi Sulawesi Tengah 94112, Indonesia 4.Dept of Pharmaceutical Chemistry, Faculty of Pharmacy, Universitas Gadjah Mada, Sekip Utara Yogyakarta 55281, Indonesia 5Dept of Pharmaceutical Biology, Faculty of Pharmacy, Universitas Gadjah Mada, Sekip Utara Yogyakarta 55281, Indonesia 6Post Graduate Student of Faculty of Pharmacy Universitas Gadjah Mada

Submitted: $15-10-2018$

Revised: 05-11-2018

Accepted: $17-11-2018$

*Corresponding author Arief Nurrochmad

Email:

ariefnr@ugm.ac.id

\begin{abstract}
Brown macroalgae (BM) which contain fucoxanthin exhibited high antioxidant activity. This study was performed to examine antioxidant, anti-collagenase, anti-elastase, antityrosinase activities, and effect on cell viability of Human Dermal Fibroblast adult (HDFa) of BM, Turbinaria decurrens Bory. $T$. decurrens dried powder were macerated by ethanol to obtain extract (ETD) and was fractination by column chromatography to obtain fraction (FTD). Fucoxanthin content was determined using HPLC. The antioxidant activities, anti-collagenase, anti-elastase, and tyrosinase inhibitory assay were performed. The effect of ETD and fucoxanthin standard on cell viability were conducted on HDFa cell-induced by hydrogen peroxide $\left(\mathrm{H}_{2} \mathrm{O}_{2}\right)$. The HPLC analysis showed that ETD and FTD contain fucoxanthin of $284.9 \pm 3.3 \mu \mathrm{g} / \mathrm{g}$ and of $653.4 \pm 30.6 \mu \mathrm{g} / \mathrm{g}$ dry-weight, respectively. The antioxidant assay showed that ETD and FTD produced high antioxidant activity by ferric reducing antioxidant power (FRAP) and $\beta$-carotene bleaching (BCB) methods that were comparable to fucoxanthin. ETD exhibited significantly higher tyrosinase inhibitory than kojic acid $(p<0.01)$, while FTD had a comparable effect to kojic acid. The result also revealed that ETD and FTD produced anti-elastase and anti-collagenase (matrix metalloproteinase-1 (MMP-1). Fucoxanthin and ETD were able to maintain cell viability on HDFa cell-induced $\mathrm{H}_{2} \mathrm{O}_{2}$. This study suggests that $T$. decurrens may be effective to prevent skin aging and wrinkle formation, possibly through the antioxidant activity and maintain cell viability of fibroblast.
\end{abstract}

Keywords: Turbinaria decurrens Bory.; fucoxanthin; antioxidant; anticollagenase; anti-elastase; anti-tyrosinase

\section{INTRODUCTION}

The aging process is characterized by the gradual alteration of skin integrity and some physiological function (Farage et al., 2008). Skin aging naturally is caused by changes in skin elasticity over time. Skin aging is predominantly is caused by exposure to ultraviolet (UV) light from radiation (photo-aging) (Jenkins, 2002; Schlotmann et al., 2001). The repeated exposure to UV light causes skin photo-aging characterized by dryness, pigmentation, laxity, and wrinkling (Gilchrest, 1996). Acute exposure to UV causes physical changes such like sunburn, inflammation, immune suppression due to the formation of lipid peroxidation, cell contents, activities of enzymes, and reactive oxygen species (ROS), whereas chronic UV exposure can disrupt normal skin architecture, photo-aging and ultimately skin cancer (Fisher $e t$ al., 2002; Quan et al., 2009). ROS such as superoxide anion radical, hydroxyl radicals, singlet oxygen, and hydrogen peroxide $\left(\mathrm{H}_{2} \mathrm{O}_{2}\right)$ formed during normal metabolic processes, which can generate the lipid peroxidation and lead to the accumulation of lipid peroxides (Rinnerthaler et al., 2015) (Wondrak et al., 2006). 
The skin enzymes such as elastase and collagenase involve in the aging process and age. The sunlight exposure (UVA and UVB) and the presence of ROS, the enzymes are produced by rapid degradation of collagen and elastin which are the main structure of extra cellular matrix (ECM) of the dermis (Landau, 2007; Svobodova et al., 2006). The exposure of UV-irradiation leads to generate ROS contributing the skin aging. ROS can also induce necrosis or apoptosis of the cells, which leads to skin aging characterized by the presence of wrinkles and skin dryness. Furthermore, the excessive of UV light exposure induced the production of excessive melanin in the skin. In the skin pigmentation, tyrosinase is the enzyme that responsible for the melanogenic process (Lin et al., 2008). The tyrosinase inhibitors are substances that commonly used as antimelanogenesis for skin whitening in the pigmentation process (Wang et al., 2011).

Active ingredients from the natural or marine sources are one of the largest compounds which used in cosmeceuticals today to reduce aging. Marine macroalgae are one of the marine sources that could potentially be exploited as functional ingredients for human health and cosmetics applications. To explore new anti-aging, marine macroalgae are being considered to be a source of nutrients, antioxidants and can be developed as an antiaging (Takaichi, 2011; Wang et al., 2015). The antioxidant of fucoxanthin in macroalgae plays an important role in mechanisms for their beneficial health effects including anti-aging (Seifried et al., 2007). However, the biological effects of carotenoids not only depend on their antioxidant activity because of other active compounds in macroalgae (Balboa et al., 2013). Formation of the excessive ROS is a widely accepted a pivotal role in the mechanism leading to skin aging. Antioxidant inhibits the damage due to free radicals or reactions promoted by ROS and finally reduce skin aging.

Body has several endogenous protection systems to diminishing excessive ROS. Several antioxidants, such as ascorbic acid, tocopherols, carotenoids, natural substances, and polyphenols, should be effective to protect oxidative stress and prevent skin aging. The bioactive compounds from natural and marine sources that possess antioxidant activity have the potential for aging prevention (Masaki, 2010). Brown macroalgae $T$. decurrens belonging to the family Phaeophyceae that have antioxidant activity. Turbinaria ornata or T. decurrens exhibited the potent antioxidant activity. The carotenoid fucoxanthin is being identified as the major component which responsible for the majority of the antioxidant activity (Kelman et al., 2012). The previous report showed that fucoxanthin also significantly decreased intracellular ROS generated by exposure to UVB radiation in human dermal fibroblast (Heo and Jeon, 2009). Fucoxanthin induced cell survival rate and inhibited the cell damage, indicating that fucoxanthin could protect skin photo-damage induced by UVB irradiation. Previous study found that fucoxanthin showed the antimelanogenic activity, which inhibited tyrosinase activity, melanogenesis process, and UUV Binduced skin pigmentation (Shimoda et al., 2010).

Using literature review, there is no published information on the antioxidant activity, anti-wrinkle and tyrosinase inhibitor of brown macroalgae of $T$. decurrens. Therefore, the present study was performed to determine antioxidant activities, anti-collagenase, antielastase, anti-tyrosinase and the effect on human dermal fibroblast of $T$. decurrens Bory.

\section{MATERIAL AND METHODS Chemicals and reagents}

All chemicals and reagents used in the study were analytical grades. Chemicals were purchased from suppliers Sigma-Aldrich (St. Louis, MO, USA) for linoleic acid, kojic acid (KA), tyrosinase (from mushroom) and L-3,4-dihydroxyphenylalanine methyl ester hydrochloride (L-DOPA), 2,4,6-tripyridyl-striazine (TPTZ), ferric chloride $\left(\mathrm{FeCl}_{3}\right)$, ferrous sulfate $\left(\mathrm{FeSO}_{4} .7 \mathrm{H}_{2} \mathrm{O}\right)$, butylated hydroxytoluene (BHT), $\beta$-carotene powder, and fucoxanthin and acetonitrile, dimethylsulfoxide (DMSO), hydrochloric acid ( $\mathrm{HCl})$, ethanol, methanol and Tween-20 were obtained from Merck KGaA (Darmstadt, Germany). Test kits (Matrix Metalloproteinase-1 (MMP-1) colorimetric drug discovery kit and Neutrophil elastase colorimetric drug discovery kit) purchased from Enzo Life Sciences, Inc. Human dermal fibroblast, adult (HDFa) (GIBCO, catalogue number C-013-5C; Lot 
number 1712286), Dulbecco's modified Eagle's medium (DMEM), trypsin, Fetal Bovine Serum (FBS), Phosphate Buffer Saline (PBS) and streptomycin/penicillin (antibiotics) were purchased from Life Technologies Corporation (GIBCO). The MTT (3-(4,5-Dimethylthiazol-2yl)-2,5-diphenyl tetrazolium bromide) obtained from BioBasic Canada Inc.

\section{Brown macroalgae}

The brown macroalgae $T$. decurrens belonging to the family Phaeophyceae was collected from Krakal Coastal, Gunung Kidul, Yogyakarta, Indonesia. The plant was botanically identified and authenticated by the Botanist (Dr. Djoko Santoso), from Dept. of Pharmaceutical Biology, Faculty of Pharmacy, Universitas Gadjah Mada, Indonesia. A voucher specimen (number AN-01-TD-16) was deposited in the Department of Pharmaceutical Biology, Faculty of Pharmacy, Universitas Gadjah Mada, Yogyakarta, Indonesia.

\section{Preparation of extract and fraction}

The extract (ETD) and fraction (FTD) of T. decurrens were prepared by macerating $1 \mathrm{~kg}$ of the dried powdered samples in $6 \mathrm{~L}$ of ethanol $96 \%$, at room temperature and protected from sunlight for $48 \mathrm{~h}$. Each extract was then filtered using Whatman's filter paper and evaporated in vacuum at $40^{\circ} \mathrm{C}$ using the rotary evaporator (Heidolph Instruments GmbH \& Co.KG, Schwabach, Germany). The isolation of Fucoxanthin-rich fraction was conducted by column chromatography with a column length of $30 \mathrm{~cm}$ and a diameter of $3 \mathrm{~cm}$ using mobile phase of chloroform: methanol $(1: 9 \mathrm{v} / \mathrm{v})$ of $150 \mathrm{~mL}$ and stationary phase silica for column mesh 80 with elution time $10-20 \mathrm{~min}$. The extract and fucoxanthin fraction of $T$. decurrens were kept in a refrigerator $\left(-80^{\circ} \mathrm{C}\right)$ and protected from sunlight until being assayed. This method yielded $8.59 \mathrm{~g}$ extract (ETD) and $2.96 \mathrm{~g}$ fraction (FTD), respectively.

\section{Determination of fucoxanthin content}

To determine the content of fucoxanthin in extract or fraction, high-performance liquid chromatography (HPLC) was used (Susanto et al., 2016). A total of $1 \mathrm{mg}$ of extract or fraction of $T$. decurrens dissolved in $1 \mathrm{~mL}$ of methanol $(1000 \mu \mathrm{g} / \mathrm{mL})$. HPLC conditions were used as follows: HPLC Elite LaChrome Equipment, pump L-2130, autosampler L-2200, UV-Vis Detector L2420, Cosmosil packed column 5C18-MS-II column size 4.61D x250mm (Hitachi High-Technologies Co., Tokyo, Japan). The mobile phase was perfored acetonitrile: methanol (70:30), the flow rate of $1 \mathrm{~mL} / \mathrm{min}$ and volume of injection of $20 \mu \mathrm{L}$. Time retention of fucoxanthin approximately 4-5min, at a wavelength of $450 \mathrm{~nm}$. Fucoxanthin content in extract and fraction were expressed in $\% \mathrm{w} / \mathrm{w}$ of extract or fraction. Fucoxanthin was used as a standard to determine fucoxanthin in extract or fraction.

\section{Antioxidant assay ferric reducing antioxidant power (FRAP)}

Antioxidant was assessed using the method of ferric reducing antioxidant power (FRAP) assay, modified from the Benzie and Strain protocol (Benzie and Strain, 1996; Benzie and Strain, 1998). The reagent for FRAP assay was prepared by mixing $300 \mathrm{mM}$ acetate buffer $(\mathrm{pH}$ 3.6), $10 \mathrm{mM} \quad$ 2,4,6-tripyridyl-S-triazine (TPTZ) solution, and $20 \mathrm{mM} \mathrm{FeCl}_{3} \cdot 6 \mathrm{H}_{2} \mathrm{O}$ in a 10:1:1 ratio. The acetate buffer $(300 \mathrm{mM})$ was prepared by mixing $3.1 \mathrm{~g}$ of sodium acetate trihydrate $\left(\mathrm{NaOAc} \cdot 3 \mathrm{H}_{2} \mathrm{O}\right)$ with $16 \mathrm{~mL}$ glacial acetic acid and added to $1 \mathrm{~L}$ with $\mathrm{ddH}_{2} \mathrm{O}$. The solution of TPTZ was prepared by mixing equal volumes of $10 \mathrm{mM}$ TPTZ with $40 \mathrm{mM} \mathrm{HCl}$. For the sample (ETD and FTD) assays, $150 \mu \mathrm{L}$ of FRAP reagent was added to each well of a 96well microtiter plate. In each well, $20 \mu \mathrm{L}$ of sample in triplicate was then added, incubated for $8 \mathrm{~min}$ at room temperature and read against blank at $595 \mathrm{~nm}$ using an absorbance microplate reader (Corona SH-1000Lab, Corona Electric Co., Ltd, Ibaraki, Japan). Triplicate standards of known $\mathrm{Fe}^{2+}$ concentrations were run simultaneously between 50 and $1000 \mu \mathrm{M}$ of $\mathrm{FeSO}_{4} \cdot 7 \mathrm{H}_{2} \mathrm{O}$. FRAP value was expressed as $\mu \mathrm{mol} \mathrm{Fe}{ }^{2+} / \mathrm{g}$ samples.

\section{Antioxidant assay using $\beta$-carotene Bleaching (BCB) \\ The $\beta$-carotene bleaching (BCB) assay} was performed according to a previous study (Karim et al., 2014). $\beta$-carotene (2 mg) was dissolved in $0.2 \mathrm{~mL}$ chloroform followed by adding $0.2 \mathrm{~mL}$ linoleic acid, two $\mathrm{mL}$ Tween 20 and added distilled water up to $100 \mathrm{~mL}$ and mix 
well. The $\beta$-carotene solution $(200 \mu \mathrm{L})$ was added to $20 \mu \mathrm{L}$ of the tested solution and incubation for $20 \mathrm{~min}$ at $50^{\circ} \mathrm{C}$. After incubation, the absorbance was monitored at $450 \mathrm{~nm}$ for $2 \mathrm{~h}$ at $30 \mathrm{~min}$ intervals using a microplate reader (Corona SH1000Lab, Corona Electric Co., Ltd, Ibaraki, Japan). Calculation of percentage of antioxidant activity was obtain by the difference of degradation rate of the tested sample to the degradation rate of control. The effective concentration of $50 \%\left(\mathrm{EC}_{50}\right)$ represents the ability of the sample to protect $50 \% \beta$-carotene solution from degradation. Butylated hydroxyltoluene (BHT) was used as positive control.

\section{Tyrosinase inhibition assay}

Tyrosinase inhibitory activity of extracts (ETD) and fraction (FTD) of T. decurrens were measured according to the previous study with a slight modification using mushroom tyrosinase as the enzyme, L-DOPA as the substrate and kojic acid as the positive control (Rangkadilok $e t$ al., 2007; Lukitaningsih and Ulrike, 2014). An aliquot $(50 \mu \mathrm{L})$ of samples in DMSO was mixed with $100 \mu \mathrm{L}$ of $200 \mathrm{IU} / \mathrm{mL}$ of mushroom tyrosinase and $100 \mu \mathrm{L}$ of phosphate buffered saline $(\mathrm{pH}$ 6.8). The reaction mixture was preincubated at $37^{\circ} \mathrm{C}$ for $10 \mathrm{~min}$ and then $100 \mu \mathrm{L}$ of L-1,4-dihydroxyphenylalanine (L-DOPA) solution $7.6 \mathrm{mM}$ was added. This reaction mixture incubated for $15 \mathrm{~min}$ at $37^{\circ} \mathrm{C}$. The dopachrome was measured at $475 \mathrm{~nm}$ using a UV/Vis spectrophotometer U-2900 (Hitachi High-Technologies Co., Tokyo, Japan). As a blank, DMSO was used (B). As a color control test, phosphate buffer was used instead of the enzyme tyrosinase (C). The percentage of tyrosinase inhibitions was expressed as a percentage of inhibition of tyrosinase activity. Kojic acid was used as a standard inhibitor for tyrosinase.

\section{Anti-collagenase activity}

Briefly $20 \mu \mathrm{L}$ of sample was diluted with $50 \mu \mathrm{L}$ buffer solution $(50 \mathrm{mM}$ HEPES, $10 \mathrm{mM} \mathrm{CaCl} 2, \quad 0.05 \%$ Brij-35 and $1 \mathrm{mM}$ Dinitrothiocyano benzene (DTNB) in DMSO). Twenty microlitres of the MMP-1 enzyme (E.coli recombinant human MMP-1 catalytic domain, $153 \mathrm{mU} / \mu \mathrm{L})$ was added to each well. Then, the reaction mixture was incubated at $37^{\circ} \mathrm{C}$ for $30 \mathrm{~min}$. Control inhibitor, NNGH (N-Isobutyl-N-(4- methoxyphenyl sulfonyl) glycylhydroxamic acid; $1.3 \mu \mathrm{M})$, was used for control inhibitor. The substrate (thiopeptide, Ac-PLG- [2-mercapto-4methyl-pentanoyl]-LG-OC $\left.\mathrm{H}_{5} ; 100 \mu \mathrm{M}\right)$ at $10 \mu \mathrm{L}$ was added to each well and absorbance was monitored using a microplate reader at $410 \mathrm{~nm}$ (Corona SH-1000Lab, Corona Electric Co., Ltd, Ibaraki, Japan) for 20min (Sciences, 2016a).

\section{Anti-elastase activity}

The anti-elastase assay, the $20 \mu \mathrm{L}$ of sample was diluted with $65 \mu \mathrm{L}$ buffer $(100 \mathrm{mM}$ HEPES, $500 \mathrm{mM} \mathrm{NaCl}$ and $0.05 \%$ ) Tween 20 in DMSO in a 96-well plate and used elastantinal $(100 \mu \mathrm{M})$ as a control inhibitor. Ten $\mu \mathrm{L}$ neutrophil elastase enzyme $2.2 \mu \mathrm{U} / \mu \mathrm{L}$ (Purified Human Neutrophil Elastase) was added to the diluted sample and incubated at $37^{\circ} \mathrm{C}$ for $20 \mathrm{~min}$. Subsequently, $5 \mu \mathrm{L}$ substrate (MeOSuc- Ala-AlaPro-Val-pNA, $100 \mu \mathrm{M}$ ) was added to each well and absorbance was monitored at $405 \mathrm{~nm}$ using absorbance microplate reader (Corona SH1000Lab, Corona Electric Co., Ltd, Ibaraki, Japan) for 10min (Sciences, 2016 ${ }^{\mathrm{b}}$.

\section{Effect on cell viability of human dermal fibroblast}

The effects of ETD and FTD on cell viability of human dermal fibroblast ( $\mathrm{HDF}$ ) were measured according to the previous study with slight modification (Karim et al., 2014). $\mathrm{HDF}$ a cells were grown from cryopreserved in DMEM containing $10 \% \mathrm{FBS}$ and $1 \%$ antibiotics. $\mathrm{HDF}$ a cells were incubated at $37^{\circ} \mathrm{C}, 95 \%$ humidity and $5 \% \mathrm{CO}_{2}$ until confluent. The medium was refreshed every two days until $80 \%$ confluence and was trypsinized with Trypsin. The cells were seeded into a 96-well microplate at a density of $1 \times 10^{5}$ per well and incubated for 24h. Serial dilution of extracts (ETD) and fraction (FTD) $T$. decurrens were added, respectively, after removal of the spent media and incubated for $24 \mathrm{~h}$. Twenty-four hours (24h) later cell then incubated with hydrogen peroxide $\left(\mathrm{H}_{2} \mathrm{O}_{2}\right) 1 \mathrm{mM}$ to induce reactive oxygen species (ROS) in the cells for $2 \mathrm{~h}$. Finally, $40 \mu \mathrm{L}$ of MTT in PBS $(2.5 \mathrm{mg} / \mathrm{mL})$ was added to each well and incubated for $4 \mathrm{~h}$, and the absorbance was measured at 550nm (Weyermann et al., 2005). The calculation of cell viability was evaluated by the optical density against the control of hydrogen peroxide $\left(\mathrm{H}_{2} \mathrm{O}_{2}\right)$. 


\section{Statistical analysis}

The results were presented as a mean \pm standard error of the mean (SEM). The comparison was made using two samples t-test or one-way analysis of variance (ANOVA) followed by a post hoc test (Bonferroni) by GraphPad Instat3 Software version 3.10 . (GraphPad Software Inc. USA). Differences between of data sets were considered to be statistically significant when $* \mathrm{p}<0.05,{ }^{* *} \mathrm{p}<0.01$ and $* * * \mathrm{p}<0.001$.

\section{RESULT AND DISCUSSION Determination of fucoxanthin content}

Fucoxanthin contained in extract (ETD), and fraction (FTD) of T. decurrens was analyzed using HPLC with UV-VIS detector at $450 \mathrm{~nm}$. The peak corresponding to fucoxanthin was detected at a retention time (tR) of $4.2 \mathrm{~min}$. The result showed that $\mathrm{tR}$ in ETD) and FTD was similar to fucoxanthin standard. The result showed that fucoxanthin contents in the extract (ETD) was $284.9 \pm 3.3 \mu \mathrm{g} / \mathrm{g}$ dry weight and that of fraction (FTD) was $653.4 \pm 30.6 \mu \mathrm{g} / \mathrm{g}$ dry weight.

The antioxidative compounds in macroalgae are important bioactive that possesses some biological activities against various diseases including aging processes. Recently, the investigation for natural antioxidants from macroalgae has been interesting. The present study showed that fucoxanthin in ETD and FTD indicated that T. decurrens contained fucoxanthin and this finding consistent with the previous study of brown macroalgae (Zailanie and Sukoso, 2014; Jaswir et al., 2013). The analysis of fucoxanthin content in the extract of $T$. decurrens yield $284.9 \mu \mathrm{g} / \mathrm{g}$ dryweight and $653.5 \mu \mathrm{g} / \mathrm{g}$ dry weight. The study of fucoxanthin content in Indonesian brown algae, Sargassum filipendula from Madura Islands yielded $195.7 \mu \mathrm{g} / \mathrm{g}$ dry-weight (Zailanie and Sukoso, 2014). The previous study reported that fucoxanthin content in Turbinaria turbinata and Sargassum plagyophyllum, two Malaysian brown seaweed yielded 590 and $710 \mu \mathrm{g} / \mathrm{g}$ dry-weight, respectively (Jaswir et al., 2013). Other study reported that the fucoxanthin content in Japanese brown seaweed Undaria pinnatifida yielded approach to $390 \mu \mathrm{g} / \mathrm{g}$ dry of $U$. pinnatifida extracted with a simple method using liquefied dimethyl ether (DME) (Kanda et al., 2014). Several line of evidences indicated that fucoxanthin content in brown seaweed was varied by region and time of collecting.

\section{Antioxidant activities}

The antioxidant activity of ETD and FTD of T. decurrens showed in Figure 1A using Ferric Reducing Antioxidant Power (FRAP) and $\beta$-carotene Bleaching (BCB) methods. The antioxidant activity showed that FRAP value of ETD and FTD at concentrations of $20 \mu \mathrm{g} / \mathrm{mL}$ was comparable to fucoxanthin but at higher concentrations ( 40 and $80 \mu \mathrm{g} / \mathrm{mL}$ ) were lower to fucoxanthin $(p<0.05)$. The antioxidant activity by $\mathrm{BCB}$ method showed that $\mathrm{EC}_{50}$ value of extract (ETD) and fraction (FTD) were $(63.73 \pm 4.09) \mu \mathrm{g} / \mathrm{mL}$ and $(57.07 \pm 2.45) \mu \mathrm{g} / \mathrm{mL}$ significantly higher than $\mathrm{BHT}$ which have $\mathrm{EC}_{50}$ of $(12.06 \pm 1.78) \mu \mathrm{g} / \mathrm{mL}(\mathrm{p}<0.001)$ (Figure 1B).

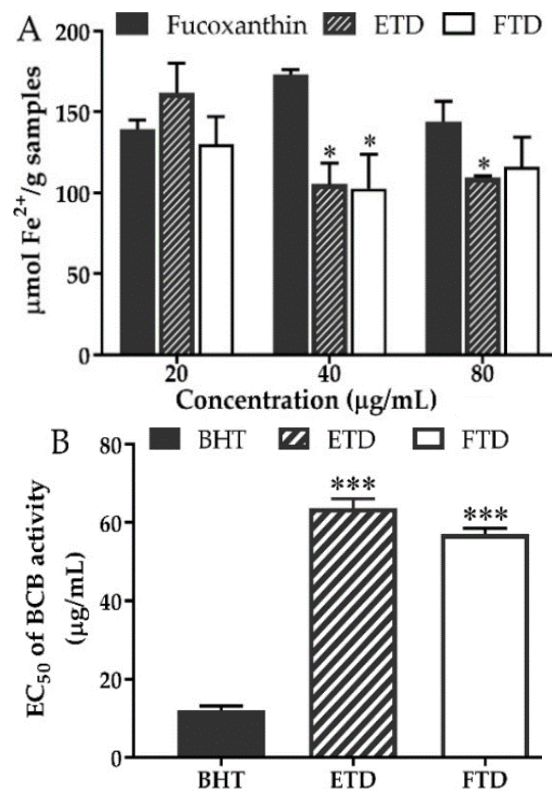

Figure 1. The antioxidant activity of ethanol extract and fractions T. decurrens (ETD and FTD) using (A) ferric reducing antioxidant power (FRAP) and (B) $\beta$-carotene bleaching (BCB) method, $\mathrm{n}=3 .{ }^{*} \mathrm{p}<0.05 ;{ }^{* * *} \mathrm{p}<0.001$ significantly different to fucoxanthin or BHT.

In the present study, ETD and FTD of $T$. decurrens produced high antioxidant activity using FRAP and BCB assay. The previous study reported one of the marine algae that have an antioxidant activity is brown macroalgae 
genera Turbinaria (Cornish and Garbary, 2010). The previous study reported that brown algae showed the highest antioxidant activity among Hawaiian algae, followed by the green algae and red algae. Among the algae tested, the extract of Turbinaria ornata was found to be the most active. The major bioactive compound that responsible for antioxidant activity in macroalgae was identified as the carotenoid fucoxanthin (Kelman et al., 2012). Another study also reported that fucoxanthin and its stereoisomers from Laminaria japonica Aresch had stronger scavenging hydroxyl radical activities than $\alpha$ tocopherol, while the radical-scavenging activities of the fucoxanthin stereoisomers were not significantly different (Zhang et al., 2014). The study indicated that ETD and FTD have potent antioxidant activities in vitro which in line with the previous studies and fucoxanthin was thought to be responsible for the activity. The allenic bond of fucoxanthin thought to play an important role in the higher antioxidant activity of fucoxanthin (Heo et al., 2008). Besides, the oxygen atoms in fucoxanthin might be more reactive to radicals (Nomura et al., 1997). It indicated that the antioxidant activity of fucoxanthin related to allenic bond and oxygen atoms.

\section{Tyrosinase inhibitor}

Tyrosinase inhibitor assay showed that ETD and FTD of T. decurrens had an inhibitory effect (Figure 2). ETD and FTD of T. decurrens had $\mathrm{IC}_{50}$ value $(295.21 \pm 41.03) \mu \mathrm{g} / \mathrm{mL}$ and (436.89 \pm 26.22$) \mu \mathrm{g} / \mathrm{mL}$, respectively. The $\mathrm{IC}_{50}$ of ETD was significantly lower $(p<0.001)$, but for FTD was comparable to kojic acid $(479.95 \pm 7.02) \mu \mathrm{g} / \mathrm{mL}$.

The excessive UV radiation leading to the generation of ROS, inflammatory, and angiogenesis which further induce cellular damage and some skin alterations such as pigmentation, erythema, laxity, wrinkling, and skin cancer (Heo and Jeon, 2009; Urikura et al., 2011). Enzyme tyrosinase was responsible for the pigmentation processes. This enzyme catalyzes two distinct significant reactions of the hydroxylation of L-tyrosine to 3,4-dihydroxy-Lphenylalanine (L-dopa) and the oxidation of Ldopa to dopaquinone, and further conversion to melanin. The exploration for skin whitening, the use of tyrosinase inhibitors is the most common approach to decrease the pigmentation processes (Wang et al., 2011). The present study showed that ETD and FTD revealed the significant inhibitor of tyrosinase that higher than kojic acid. The results are consistent with the previous report that fucoxanthin isolated from Laminaria japonica has been reported to inhibit tyrosinase activity in UVB-irradiated guinea pigs and melanogenesis in UVBirradiated mice. It seems that fucoxanthin had an anti-pigmentary activity by the topical or oral application (Shimoda et al., 2010).

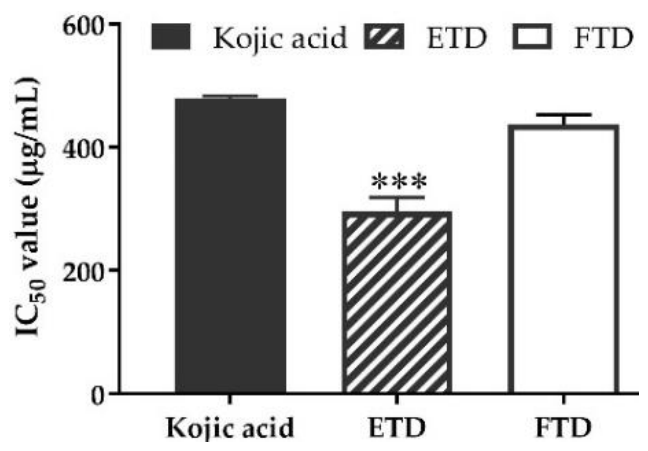

Figure 2. The inhibitory activity of ethanol extracts and fractions $T$. decurrens (ETD and FTD) on the enzyme tyrosinase, $\mathrm{n}=3$. *** $\mathrm{p}<0.001$ significantly different to kojic acid. The inhibitory effect represented in $\mathrm{IC}_{50}$.

\section{Elastase and collagenase inhibitor}

The elastase enzyme in the present study used human neutrophil elastase and matrix metalloproteinase-1 (MMP-1) for collagenase. The result showed that ETD and FTD (40 and $80 \mu \mathrm{g} / \mathrm{mL}$ ) produced elastase inhibitions, which the inhibition higher than elastantinal $(\mathrm{p}<0.05)$ (Figure 3A). Likewise, ETD and FTD of $T$. decurrens produced MMP-1 inhibition markedly $(\mathrm{p}<0.001)$ (Figure 3B). The ETD and FTD showed the inhibition of the enzyme for both enzymes. It seems that extra cts and fractions of T.decurrens (ETD and FTD) have the potential to inhibit collagenase and elastase so that it can be developed as an anti-wrinkle (Wirasti, 2016).

MMP is member of proteinases that are responsible for degrading extra cellular matrix (ECM) proteins, which form skin dermal connective tissue (Urikura et al., 2011; Sternlicht and Werb, 2001). Fisher group and others reported that UV radiation increased the expression level of at least three different MMPs 

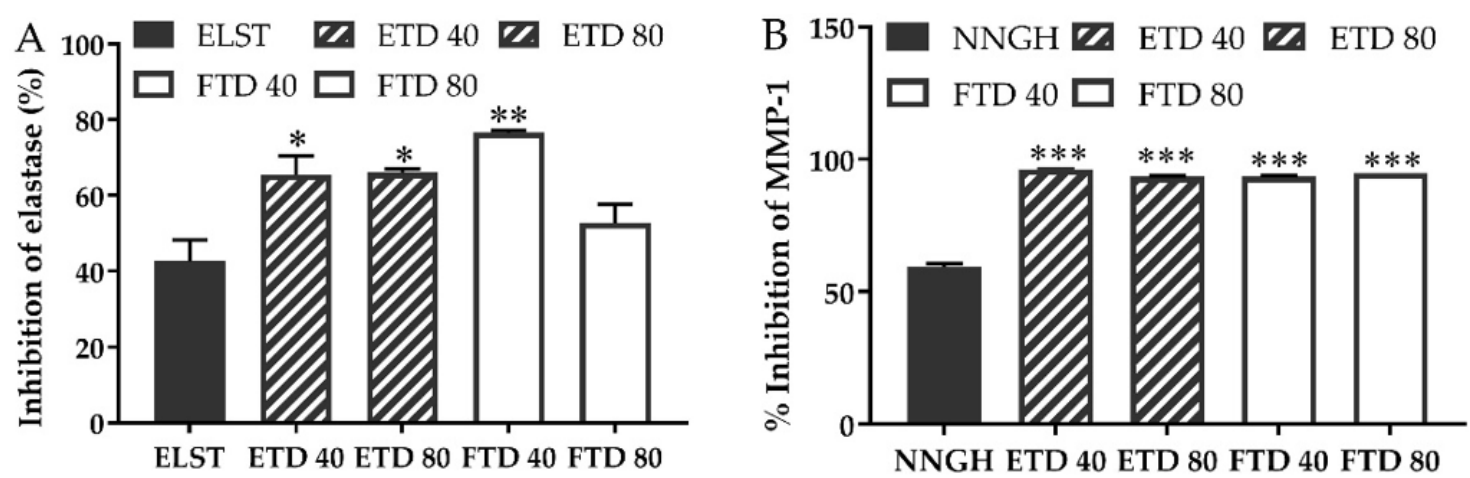

Figure 3. The inhibitory activity of ethanol extracts and fractions T. decurrens (ETD and FTD) on (A) human neutrophil elastase and (B) matrix metalloproteinase-1 (MMP-1), $\mathrm{n}=3$. ${ }^{*} \mathrm{p}<0.05 ;{ }^{* * *} \mathrm{p}<0.001$, significantly different to elastantinal (ELST) or NNGH.
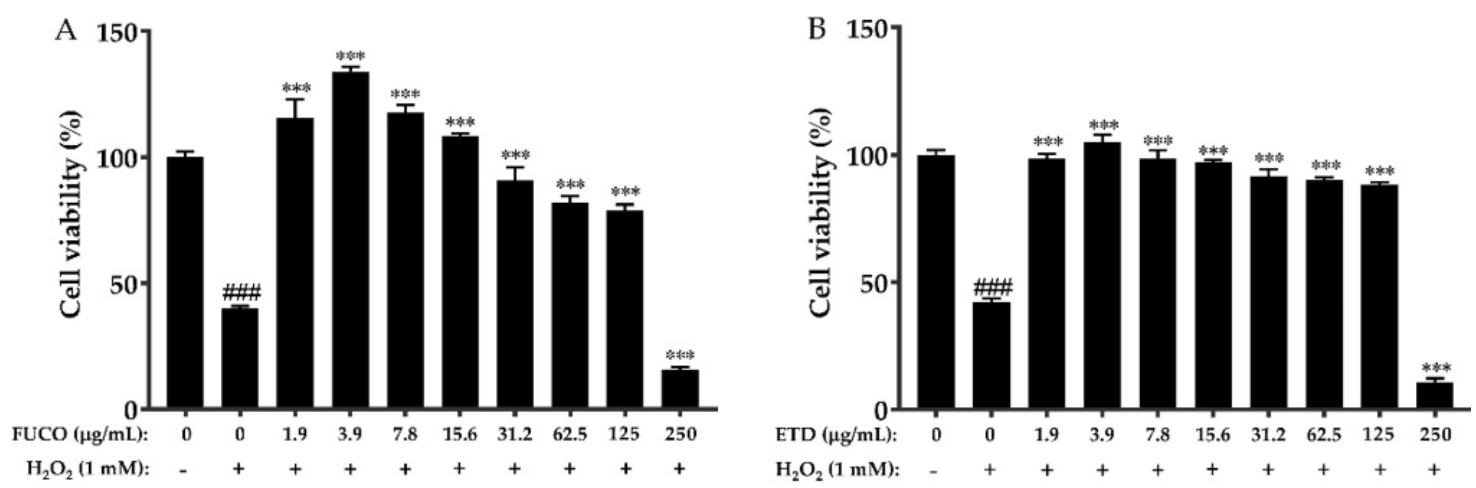

Figure 4. Effect of (A) fucoxanthin (FUCO) and (B) ethanolic extract of T. decurrens (ETD) on cell viability of Human Dermal Fibroblast $(\mathrm{HDF})$-induced hydrogen peroxide $\left(\mathrm{H}_{2} \mathrm{O}_{2}\right), \mathrm{n}=3$. ${ }^{*} \mathrm{p}<0.05$; ${ }^{* * *} \mathrm{p}<0.001$, significantly different to elastantinal or $\mathrm{NNGH}$. \#\#\# $\mathrm{p}<0.001$, significantly different to control cells without $\mathrm{H}_{2} \mathrm{O}_{2}$.

in human skin in vivo such interstitial collagenase (MMP-1), stromelysin-1 (MMP-3), and 92-kDa gelatinase (MMP-9) (Quan et al., 2009; Sternlicht and Werb, 2001; Wang et al., 2008). The MMP$1,-3$, and -9 can degrade most of the proteins that comprise the dermal ECM (Quan et al., 2009). The transcription factor of activator protein 1 (AP-1) plays an important role in the transcriptional regulation of MMP-1 (Joe et al., 2006). UVB and UVA induce the formation of ROS, which potential to activate blood neutrophils and induce elastin dystrophy. In this condition, neutrophils can infiltrate the skin to secrete neutrophil elastases and activate MMPs. Next, MMP-2 and MMP-9, degrade collagens and elastic fibers leading to induce loss of skin elasticity, wrinkle formation, and accelerating skin aging (Inomata et al., 2003). MMPs break down the ECM and induce skin damage that characterized by skin wrinkle. Our findings demonstrated that extract (ETD) and fraction (FTD) of T. decurrens were able to inhibit MMP1 and human neutrophile elastase in vitro that indicating have an anti-wrinkle effect.

\section{Cells viability of Human Dermal Fibroblast adult (HDFa)}

The exposure of hydrogen peroxide $\left(\mathrm{H}_{2} \mathrm{O}_{2}\right)$ exhibited the cell cytotoxic on $\mathrm{HDFa}$ cell. The addition of $\mathrm{H}_{2} \mathrm{O}_{2}$ was able to decrease cell viability on $\mathrm{HDFa}$ cells by approximately $60 \%$. Because of its antioxidant activity, tyrosinase, elastase, and collagenase inhibitor of ETD and FTD were not significantly different. 
Therefore, only ETD tested on $\mathrm{HDF}$ a cell viability. As shown in Figure $4 \mathrm{~A}-\mathrm{B}, \mathrm{H}_{2} \mathrm{O}_{2}$ treatment without fucoxanthin or ETD decreased cell viability to $60.15 \%$ (A) and $57.77 \%$ (B), while fucoxanthin and ETD prevented cells from $\mathrm{H}_{2} \mathrm{O}_{2}$-induced damage, restoring the cell survival (78.94-133.96)\% and (88.26-104.98)\%, at the range concentrations of 1.9 to $125 \mu \mathrm{g} / \mathrm{mL}$, respectively. The cell viability profile indicated that fucoxanthin and ETD showed the biphasic effect on cell growth. At lower concentration, $(<3.9 \mu \mathrm{g} / \mathrm{mL})$ fucoxanthin and ETD were able to induce cell viability, but up to concentration to $125 \mu \mathrm{g} / \mathrm{mL}$ gradually decrease cell viability. The effect of fucoxanthin and ETD more than $125 \mu \mathrm{g} / \mathrm{mL}$ induced cytotoxic on HDFa cells drastically (Rahmawati, 2017).

In experimental models Hydrogen peroxide has been extensively used to induce oxidative stress in vitro. It readily crosses the cellular membranes in the cells and giving rise to the highly reactive hydroxyl radical, which can react with macromolecules, including DNA, proteins, and lipids, and ultimately cell damage (Satoh et al., 1996). This study showed that fucoxanthin and ETD prevented cells from $\mathrm{H}_{2} \mathrm{O}_{2}$-induced damage, restoring cell survival in HDFa. The result in line with the previous study that fucoxanthin isolated from Sargassum siliquastrum can effectively inhibit intracellular ROS formation, DNA damage, and apoptosis induced by $\mathrm{H}_{2} \mathrm{O}_{2}$, possibly due to the increase of catalase activity (Heo et al., 2008). Furthermore, treatment of fucoxanthin significantly decreased intracellular ROS generated by exposure to UV$B$ radiation, increased cell survival rate in pretreated cells, and inhibited cell damage in human (Heo and Jeon, 2009). Antioxidants are believed to be an effective approach to preventing skin damage related to photo-aging (Masaki, 2010). In this study, the antioxidant activity may play an important role in preventing damage to fibroblast cells induced by $\mathrm{H}_{2} \mathrm{O}_{2}$.

\section{CONCLUSION}

Extract (ETD) and fraction (FTD) of $T$. decurrens, one of the brown seaweeds macroalgae containing fucoxanthin, have antioxidant activities, tyrosinase inhibitor and significantly inhibit MMP-1, human neutrophil elastase, and prevented cells from $\mathrm{H}_{2} \mathrm{O}_{2}$-induced damage, restoring cell survival in HDFa. This study suggested that $T$. decurrens may be effectively prevented skin aging and wrinkle formation, possibly through the antioxidant activity. Our findings may give the evidence supporting the development of cosmeceutical from marine algae. Moreover, further study needed in extensive animal experimentation and wellcontrolled clinical trials.

\section{ACKNOWLEDGEMENT}

This study project was supported by Penelitian Unggulan Perguruan Tinggi, (Grant number: 626/UN1-P.III/LT/DIT-LIT/2016 from the Directorate of Study and Community Services, Ministry of Study, Technology and Higher Education, Republic of Indonesia.

\section{REFERENCES}

Balboa EM., Conde E., Moure A., Falqué E., Domínguez H., 2013. In vitro antioxidant properties of crude extracts and compounds from brown algae. Food Chemistry. 138(2-3):1764-1785.

Benzie IFF., Strain JJ., 1998. Ferric reducing/antioxidant power assay: Direct measure of total antioxidant activity of biological fluids and modified version for simultaneous measurement of total antioxidant power and ascorbic acid concentration. Methods in Ensymology, 299:15-27.

Benzie IF., Strain JJ., 1996. The ferric reducing ability of plasma (FRAP) as a measure of "antioxidant power": the FRAP assay. Analytical Biochemistry, 239(1):70-76.

Cornish M., Garbary D., 2010. Antioxidants from macroalgae: potential applications in human health and nutrition. Algae, 25(4):155-171.

Farage MA., Miller KW., Elsner P., Maibach, HI., 2008. Intrinsic and extrinsic factors in skin ageing: a review. International Journal of Cosmetic Science, 30(2):87-95.

Fisher, GJ., Kang, S., Varani, J., Bata-Csorgo, Z., Wan, Y., Datta, S., Voorhees, JJ. 2002. Mechanisms of photoaging and chronological skin aging. Archives of Dermatology, 138(11):1462-1470.

Gilchrest BA., 1996. A review of skin ageing and its medical therapy. The British Journal of 
Dermatology, 135(6):867-875.

Heo SJ., Jeon YJ., 2009. Protective effect of fucoxanthin isolated from Sargassum siliquastrum on UV-B induced cell damage. Journal of Photochemistry and Photobiology B: Biology, 95(2):101-107.

Heo SJ., Ko SC., Kang SM., Kang HS., Kim JP., Kim SH., Lee KW., Cho MG., Jeon, YJ., 2008. Cytoprotective effect of fucoxanthin isolated from brown algae Sargassum siliquastrum against $\mathrm{H}_{2} \mathrm{O}_{2-}$ induced cell damage. European Food Research and Technology, 228(1):145-151.

Inomata S., Matsunaga Y., Amano S., Takada, K., Kobayashi, K., Tsunenaga, Nishiyama T, Kohno Y, Fukuda M., 2003. Possible involvement of gelatinases in basement membrane damage and wrinkle formation in chronically ultraviolet Bexposed hairless mouse. Journal of Investigative Dermatology, 120(1):128-134.

Jaswir I., Dedi N., Salleh HM., Taher M., Miyashita K., Ramli N., 2013. Analysis of fucoxanthin content and purification of all-trans-fucoxanthin from Turbinaria turbinata and Sargassum plagyophyllum by $\mathrm{SiO}_{2}$ open column chromatography and reversed phase HPLC. Journal of Liquid Chromatography, 6076:1340-1354.

Jenkins G., 2002. Molecular mechanisms of skin ageing. Mechanisms of Ageing and Development, 123(7):801-810.

Joe MJ., Kim SN., Choi HY., Shin WS., Park GM., Kang DW., Kim YK., 2006. The inhibitory effects of eckol and dieckol from Ecklonia stolonifera on the expression of matrix metalloproteinase-1 in human dermal fibroblasts. Biological \& Pharmaceutical Bulletin, 29(8):1735-1739.

Kanda H., Kamo Y., Machmudah S., Wahyudiono, Goto M., 2014. Extraction of fucoxanthin from raw macroalgae excluding drying and cell wall disruption by liquefied dimethyl ether. Marine Drugs, 12(5):2383-2396.

Karim AA., Azlan A., Ismail A., Hashim P., Abd Gani SS., Zainudin BH., Abdullah NA., 2014. Phenolic composition, antioxidant, anti-wrinkles and tyrosinase inhibitory activities of cocoa pod extract. BMC Complementary and Alternative Medicine, 14(1):381.
Kelman D., Posner EK., McDermid KJ., Tabandera NK., Wright PR., Wright AD., 2012. Antioxidant activity of Hawaiian marine algae. Marine Drugs, 10(2):403416.

Landau M., 2007. Exogenous factors in skin aging. Current Problems in Dermatology, 35:1-13.

Lin JW., Chiang HM., Lin YC., Wen KC., 2008. Natural products with skin - Whitening effects. Journal of Food and Drug Analysis, 16(2):1-10.

Lukitaningsih E., Ulrike H., 2014. Bioactive Compounds In Bengkoang (Pachyrbizus erosus) as Antioxidant and Tyrosinase Inhibiting Agents. Indonesian J Pharm, 25(2):68-75.

Masaki H., 2010. Role of antioxidants in the skin: Anti-aging effects. Journal of Dermatological Science, 58(2):85-90.

Nomura T., Kikuchi M., Kubodera A., Kawakami Y., 1997. Proton-donative antioxidant activity of fucoxanthin with 1,1-diphenyl-2-picrylhydrazyl (DPPH). Biochemistry and Molecular Biology International, 42(2):361-370.

Quan T., Qin Z., Xia W., Shao Y., Voorhees J J., Fisher GJ., 2009. Matrix-degrading metalloproteinases in photoaging. The Journal of Investigative Dermatology. Symposium Proceedings, 14(1):20-24.

Rahmawati A. 2017. Aktivitas Ekstrak Etanol Rumput Laut Coklat (Turbinaria decurrens) Terhadap Viabilitas Sel Human Dermal Fibroblast Adult (HDFa) Sebagai Salah Satu Uji Aanti Aging. Skripsi, Fakultas Farmasi, Universitas Gadjah Mada.

Rangkadilok N., Sitthimonchai S., Worasuttayangkurn L., Mahidol C., Ruchirawat M., Satayavivad J., 2007. Evaluation of free radical scavenging and antityrosinase activities of standardized longan fruit extract. Food and Chemical Toxicology, 45(2):328-336.

Rinnerthaler M., Bischof J., Streubel MK., Trost A., Richter K., Breitenbach M., Eckl P., 2015. Oxidative Stress in Aging Human Skin. Biomolecules, 5:545-589.

Satoh T., Sakai N., Enokido Y., Uchiyama Y., Hatanaka H., 1996. Free radicalindependent protection by nerve growth factor and $\mathrm{Bcl}-2$ of $\mathrm{PC} 12$ cells from 
hydrogen peroxide-triggered apoptosis. Journal of Biochemistry, 120(3):540-546.

Schlotmann K., Kaeten M., Black AF., Damour O., Waldmann-Laue M., Forster T., 2001. Cosmetic efficacy claims in vitro using a three-dimensional human skin model. International Journal of Cosmetic Science, 23(5):309-318.

Sciences EL., 2016a. Matrix Metalloproteinase-1 (MMP-1) colorimetric drug discovery kit. Retrieved May 8, 2016, from http://www.enzolifesciences.com/BML -AK 404/matrixmetalloproteinase-1-\% 0Ammp-1-colorimetric-drug-discoverykit

Sciences EL., 2016b. Neutrophil elastase colorimetric drug discovery kit. Retrieved June 10, 2016, from http://www.enzolifesciences.com/BML -AK497/neutrophil-elastasecolorimetricdrugdiscovery-kit $\% 0 \mathrm{~A}$

Seifried HE., Anderson DE., Fisher EI., Milner JA., 2007. A review of the interaction among dietary antioxidants and reactive oxygen species. The Journal of Nutritional Biochemistry, 18(9):567-579.

Shimoda H., Tanaka J., Shan SJ., Maoka T., 2010. Anti-pigmentary activity of fucoxanthin and its influence on skin mRNA expression of melanogenic molecules. The Journal of Pharmacy and Pharmacology, 62(9):1137-1145.

Sternlicht MD., Werb Z., 2001. How matrix metalloproteinases regulate cell behavior. Annual Review of Cell and Developmental Biology, 17:463-516.

Susanto E., Suhaeli A., Abe M., 2016. Lipids, Fatty Acids, and Fucoxanthin Content from Temperate and Tropical Brown Seaweeds. Aquatic Procedia, 7:66-75.

Svobodova A., Walterova D., Vostalova J., 2006. Ultraviolet light induced alteration to the skin. Biomedical Papers of the Medical Faculty of the University Palacky, Olomouc, Crechoslovakia, 150(1):25-38.

Takaichi S., 2011. Carotenoids in algae: distributions, biosyntheses and functions. Marine Drugs, 9(6):1101-1118.

Urikura I., Sugawara T., Hirata T., 2011.
Protective effect of Fucoxanthin against UVB-induced skin photoaging in hairless mice. Bioscience, Biotechnology, and Biochemistry, 75(4):757-760

Wang F., Garza LA., Cho S., Kafi R., Hammerberg C., Quan T., Hamilton T., Mayes M., Ratanatharathorn V., Voorhees JJ., Fisher GJ., Kang S., 2008. Effect of increased pigmentation on the antifibrotic response of human skin to UV-A1 phototherapy. Archives of Dermatology, 144(7):851-858.

Wang HM., Chen CY., Wen ZH., 2011. Identifying melanogenesis inhibitors from Cinnamomum subavenium with in vitro and in vivo screening systems by targeting the human tyrosinase. Experimental Dermatology, 20(3):242-248.

Wang HD., Chen CC., Huynh P., Chang JS., 2015. Exploring the potential of using algae in cosmetics. Bioresource Technology. 184:355-362.

Weyermann J., Lochmann D., Zimmer A., 2005. A practical note on the use of cytotoxicity assays. International Journal of Pharmaceutics, 288(2):369-376.

Wirasti, 2016. Uji Aktivitas Antioksidan dan Anti Penuaan Dini Rumput Laut Coklat (Turbinaria decurrens Bory). Thesis Fakultas Farmasi, Universitas Gadjah Mada.

Wondrak GT., Jacobson MK., Jacobson EL., 2006. Endogenous UVAphotosensitizers: mediators of skin photodamage and novel targets for skin photoprotection. Photochemical \& Photobiological Sciences, 5(2):215-237.

Zailanie K., Sukoso., 2014. Study on of Fucoxanthin Content and its Identification in Brown Algae from Padike Village Talango District, Madura Islands. Journal of Life Science and Biomedicine, 4(1):1-3.

Zhang Y., Fang H., Xie Q., Sun J., Liu R., Hong Z., Yi R., Wu H., 2014. Comparative Evaluation of the Radical-Scavenging Activities of Fucoxanthin and Its Stereoisomers. Molecules, 19(2):21002113. 